\title{
Przemiany zagospodarowania terenów portowo-przemysłowych aglomeracji Trójmiasta
}

\section{Struktura dzielnic portowo-przemyslowych Trójmiasta}

Podstawą gospodarki regionu, a zwłaszcza dwóch jego największych miast - Gdańsk i Gdyni, jest gospodarka morska, a więc przede wszystkim porty morskie, stocznie oraz szereg zakładów produkcyjnych, pośrednio lub bezpośrednio związanych $\mathrm{z}$ działalnością przeładunkową portów. Obecnie w Trójmieście znajdują się 3 obszary portowe: Port Wewnętrzny w Gdańsku, Port Gdynia oraz Port Północny w Gdańsku. Zespół portów Trójmiasta jest największy na południowym Bałtyku i jego obroty stanowią 57,7\% polskich przeładunków drogą morską (wzrost o 4,3\% w porównaniu z 1997 rokiem). Porty te także przeładowują 53,2\% ładunków tranzytowych (wzrost o 34,1\% w porównaniu z 1997 rokiem).

Łączne przeładunki w obu portach w 1999 wynosiły 26,6 miliona ton, z czego na porty Gdańska przypadało 18,8 miliona. Porty mają wyraźną specjalizację: większość paliw płynnych, węgla oraz masowych surowców chemicznych przeładowuje się w porcie gdańskim, zaś drobnicę, kontenery i zboża głównie w porcie gdyńskim. Oba zarządy portów prowadzą przy tym intensywne prace inwestycyjne, mające na celu podniesienie ich konkurencyjności, przed wszystkim względem sąsiadującego portu konurbacji.

Obecna lokalizacja oraz struktura wewnętrzna obszarów portowych Trójmiasta została ukształtowana w wyniku szeregu procesów historycznych. Najstarszy obszar portowy regionu zajmował tereny po obu brzegach Motławy, w bezpośrednim sąsiedztwie Starego i Glównego Miasta w Gdańsku. W 19. wieku, wraz z rozwojem technologii oraz zwiększaniem się wielkości statków, zasadnicze tereny przeładunkowe przeniesiono w rejon Nowego Portu, w pobliżu ujścia Martwej Wisły do Zatoki Gdańskiej; są to tereny obecnego Portu Wewnętrznego. We wczesnych latach 20. ubiegłego wieku rozpoczęto budowę portu w Gdyni, u wylotu Pradoliny Kaszubskiej, pomiędzy Kamienną Górą a Kępą Oksywską. Najnowszym natomiast kompleksem portowym w Trójmieście jest Port Pólnocny w Gdańsku, wybudowany jako port zewnętrzny w latach 70. dwudziestego wieku.

Struktura funkcjonalna dzielnic portowych Trójmiasta wynika w znacznej mierze z uwarunkowań historycznych oraz możliwości funkcjonalnych. Najstarsza, nadmotławska cześć portu gdańskiego, w pobliżu Wyspy Spichrzów, Ołowiani i Śródmieścia pełni jedynie funkcje magazynowe oraz turystyczne, dzięki lokalizacji przystani żeglugi przybrzeżnej oraz mariny jachtowej. Port Wewnętrzny w Gdańsku podzielony jest przez Martwą Wisłę na Zachodni oraz Wschodni Brzeg. Po zachodniej stronie rzeki zlokalizowano bazę promową terminale zbożowe, drobnicowe, a także stocznie - Gdańską, Północną, Remonto- 
wą, elektrociepłownię oraz tereny składowe. Wschodni Brzeg skupia natomiast przeładunek produktów chemicznych (głownie fosforytów i siarki), drewna i węgla oraz stocznię jachtową, Gdańskie Zakłady Nawozów Fosforowych i Siarkopol. Port Północny wykorzystywany jest niemal wyłącznie do przeładunku ropy naftowej i paliw płynnych oraz węgla kamiennego, natomiast w jego pobliżu zlokalizowano Rafinerię Gdańską, która jest największym zakładem przemysłowym regionu.

Port w Gdyni znajduje się w odległości około $20 \mathrm{~km}$ od poru gdańskiego. Składa się on z Portu Wschodniego, z terminalami zbożowymi, drobnicowymi, do przeładunku paliw płynnych i węgla oraz Portu Zachodniego, z dwoma terminalami: kontenerowym i promowym. W bezpośrednim sąsiedztwie portu gdyńskiego znajdują się także takie zakłady przemysłowe jak Stocznia Gdynia, Marynarki Wojennej, remontowe Nauta i Radunia oraz zakłady elektrotechniczne „Radmor”, elektrociepłownia, rozlewnia „Coca-Coli”, lokomotywownia, baza Marynarki Wojennej, Przedsiębiorstwo Połowów Dalekomorskich „Dalmor" $i$ inne.

\section{Przemiany i rewitalizacja}

Zasadniczym celem przemian struktury, zarówno funkcjonalnej, jak i przestrzennej, jest zazwyczaj chęć zwiększenia efektywności bądź lepszego wykorzystania istniejących zasobów. Przemiany zagospodarowania terenów zainwestowanych mają zatem na celu generalną poprawę poziomu ich rentowności, zarówno w ekonomicznym, jak i społecznym znaczeniu. Można więc mówić o rewitalizacji terenów, w etymologicznym znaczeniu tego słowa, czyli przywracaniu do życia, czy dawnej świetności. Ten powrót słabo lub niewykorzystanych terenów do życia gospodarczego miasta i regionu może odbywać się w dwojaki sposób: bez zmiany funkcji, w analizowanym przypadku - przy zachowaniu i intensyfikacji funkcji portowo - przemysłowych i ze zmianą funkcji, w kierunku wyższego rzędu, np. usług specjalistycznych, funkcji ogólnomiejskich czy produkcyjnych.

Przemiany terenów portowych Gdańska rozpoczęły się na większą skalę już w XIX. wieku, wraz z przeniesieniem działalności przeładunkowej do Nowego Portu. Tak więc przemiany funkcjonalne dotknęły już wówczas Lasztownię, w której koncentrowało się budownictwo statków oraz tereny magazynowe i przeładunkowe Wyspy Spichrzów i Ołowianki. Obszary leżące po zachodniej stronie Motławy zostały w większości wchłonięte przez tkankę miejską i zagospodarowane przez budynki mieszkalne oraz handlowe. Pozostałe obszary, czyli wyspy i większość lewego brzegu Motławy, pełniły funkcje magazynowe (głównie spichlerze zbożowe) oraz przemysłowe (elektrownia, rzeźnie i inne zakłady przetwórcze). Ten typ wykorzystania terenu dominował do 1945, od kiedy, w wyniku zniszczeń okresu wojny, znaczna część wysp i zachodniego brzegu Motławy pozostały nieodbudowane i były de facto nieużytkami. Odbudowano po wojnie większość zakładów przemysłowych, zaś funkcje składowe pełniła południowa część Wyspy Spichrzów.

Obecnie część terenów Wyspy Spichrzów, na przedłużeniu Traktu Królewskiego, czyli ulica Stągiewna, pełni funkcje ogólnomiejskie, w tym handlowe, usługowe i mieszkaniowe, po odbudowie, czy raczej rekonstrukcji, ciągu budynków Stągiewnej. Przez Wyspę przebiega trasa szybkiego ruchu do Warszawa (A-1), zlokalizowano tam także hotel. Natomiast odbudowane spichlerze Ołowianki są częścią ekspozycji Centralnego Muzeum Morskiego, zaś nieczynną od kilku lat elektrownię zamieniono na, będącą w stadium reali- 
zacji, salę koncertową Filharmonii Bałtyckiej w Gdańsku. W zasadzie wszystkie zakłady produkcyjne tej dzielnicy upadły na początku lat 90 ., zaś ich często zabytkowe zabudowania, z uwagi na restrykcyjne uwarunkowania konserwatorskie, pozostają niewykorzystane systematycznie i stopniowo popadają w ruinę ${ }^{1}$.

Przemiany funkcjonalne zachodzą także na terenach byłej Stoczni Cesarskiej, potem im. Lenina, następnie Gdańskiej. Po upadku stoczni i przejęciu części produkcyjnej przez Stocznię Gdyńską, część terenów stoczniowych zmieniła swoje użytkowanie. W jednej z hal otwarto największą dyskotekę w mieście, zaś okolice historycznej Bramy Nr 2, wraz z Salą BHP, zajmuje utworzone w 2000 roku Muzeum Solidarności.

Pewne zmiany zaszły także w użytkowaniu terenów ściśle porowych. Część nabrzeży, zwłaszcza Wschodniego Brzegu, przestała być wykorzystywana w celach przeładunkowych, co wynika $\mathrm{z}$ ogólnego spadku przeładunków w porcie gdańskim w ostatnich 20 latach. Dotyczy to szczególnie terenów składowych drewna, co wiąże się z praktycznym zaniechaniem eksportu tego produktu przez port gdański. Dodatkowo niektóre z nabrzeży nie spełniają obecnych wymogów technicznych, co praktycznie, przy braku znacznych nakładów modernizacyjnych, wyklucza je z funkcji przeładunkowych. Wyraźna ekstensyfikacja wykorzystania terenów portowych dotknęła przede wszystkim południowej i wschodniej część Portu Wewnętrznego. Dodatkową zauważalną zmianą ostatnich 10 lat jest stopniowy rozwój przemysłu przetwórczego na terenach potowych, często przy udziale kapitału zagranicznego (np. niemiecka przetwórnia słowu i inne).

Przemiany terenów portowych Gdyni, z uwagi na stosunkowo krótką historię portu, nie są zbyt daleko posunięte. Do zasadniczych przemian można zaliczyć utratę racji bytu terminalu pasażerskiego w latach 80., wraz z zamknięciem ostatniej linii transatlantyckiej. Obecnie Dworzec Morski pełni funkcje magazynowe i częściowo przetwórcze ${ }^{2}$. Przemiany organizacyjne transportu kolejowego spowodowały natomiast ograniczenie wykorzystania, a częściowo nawet zaniechanie użytkowania znacznych obszarów wykorzystywanych do przetaczania składów kolejowych, tzw. Międzytorza, położonego między Portem Wschodnim a Śródmieściem Gdyni.

Zasadnicze zamiany w zagospodarowaniu terenów dzielnicy portowej zaszły na pograniczu Śródmieścia i Międzytorza, na terenach dawnych hal magazynowych firm, związanych z portem. Większość budynków pełni obecnie funkcje handlowe, zarówno handlu detalicznego, jak i hurtowego, natomiast największa z hal, przez kilka lat pełniła funkcje wystawiennicze dla World Trade Certer Gdynia, a po zaniechaniu działalności tej firmy, została przejęta przez Międzynarodowe Targi Gdańskie, które organizują tam liczne imprezy handlowo - wystawiennicze.

Także niektóre z nabrzeży, z wyniku spadku przeładunków, zwłaszcza węgla, oraz postępującej dekapitalizacji, są wykorzystywane w nieznacznym stopniu. Zauważalny jest także w Gdyni, podobnie jak w Gdańsku, rozwój przemysłu podnoszącego wartość towarów transportowanych drogą morską (value adding).

\footnotetext{
'Znaną metodą omijania regulacji konserwatorskich są "przypadkowe" pożary zabytkowych obiektów, które już kilkakrotnie dotknęły budynków dawnej rzeźni w Gdańsku. Po kilku pożarach obiekty będą nadawać się wyłącznie do rozbiórki, co zdecydowanie obniża koszty inwestycji w atrakcyjnej częśsi miasta.

${ }^{2}$ Między innymi jako dojrzewalnia bananów.
} 


\section{Planowane inwestycje i przyszłe kierunki przemian dzielnic portowych}

Przyszły rozwój dzielnic portowo - przemysłowych zależy w zasadniczej mierze od intencji i aktywności ich właściciela, którym praktycznie pozostaje Skarb Państwa, bądź Gmina ( w przypadku terenów Wyspy Spichrzów w Gdańsku). To od właściciela i jego chęci rewitalizacji zależy pozyskanie inwestorów oraz przemiany funkcjonalne. Do zasadniczych planów zamieniających stan lub poziom zagospodarowania terenów portowo przemysłowych w Trójmieście należą następujące grupy inwestycji:

- Rozwój działalności przeładunkowej. Planuje się budowę dużych, nowych terminali przeładunkowych na niewykorzystywanych terenach w pobliżu Portu Północnego w Gdańsku: kontenerowego, zbożowo - paszowego, płynnych surowców chemicznych oraz terminalu rudowego. Inwestycje w Gdyni zakładają rewitalizację i modernizację starej, wschodniej części portu, połączone z budową terminalu Ro-Ro oraz nowych urządzeń portowych i magazynów. Planuje się także budowę nowej, dużej bazy promowej, w sąsiedztwie obecnej, tymczasowej w zachodniej części portu gdyńskiego.

- Nowe rozwiązania komunikacyjne, łączące porty z zapleczem, w tym dokończenie trwającej budowy Trasy Sucharskiego w Gdańsku, z wiszącym Mostem Sucharskiego, który połączy wschodnią część portu z trasą do Warszawy. W Gdyni natomiast trwają prace przy zakończeniu budowy Estakady Kwiatkowskiego, łączącej zachodni port $\mathrm{i}$ bazę kontenerową i promową $\mathrm{z}$ głównymi arteriami komunikacyjnymi miasta. W dalszej perspektywie planuje się bezpośrednie połączenie Estakady z Obwodnicą Trójmiasta w Gdyni oraz budowę tunelu drogowego pod Martwą Wisłą, który połączyłby wschodni i zachodni port oraz ulicy Nowej Wałowej w Gdańsku, łączącej tereny postoczniowe z układem komunikacyjnym Śródmieścia.

- Inwestycje produkcyjne na terenach portowych bądź przyportowych, skierowane głównie na uszlachetnianie towarów transportowanych drogą morską. Planowane bądź będące w stadium realizacji są obecnie inwestycje przetwórcze w przemyśle spożywczym, mineralnym, a także elektromaszynowym, zarówno w Gdańsku, jak i w Gdyni.

- Inwestycje w sferze usług ogólnomiejskich i wyższego rzędu. Są to najbardziej kapitałochłonne i najbardziej śmiałe projekty, wykorzystujące centralne położenie dzielnic portowych. Planuje się poszerzenie centrum Gdańska o część terenów postoczniowych oraz Wyspy Spichrzów. Natomiast w Gdyni opracowano plany rozbudowy Śródmieścia o Międzytorze oraz w perspektywie zakłada się przejęcie przez funkcje ogólnomiejskie, należącego do Dalmoru, Mola Rybackiego. Plany te zależą głównie od możliwości i umiejętności pozyskania zewnętrznych (przede wszystkim zagranicznych) inwestorów o znaczącym potencjale finansowym.

Największe szanse na realizację ma projekt zagospodarowania terenów postoczniowych w Gdańsku, a to z uwagi na amerykańskiego inwestora, który jest współwłaścicielem tych terenów. Zakłada się tam budowę nowoczesnego centrum wielkomiejskiego, z frontem wodnym (water front), licznymi obiektami usługowymi, biurowymi oraz mieszkaniowymi. Opracowano obecnie szereg koncepcji architektonicznych tego terenu, uwzględniających także walory istniejących tam obiektów zabytkowych (stuletnich budynków dawnej Stoczni Cesarskiej, objętych ochroną konserwatorską). 
Dzielnice portowo - przemysłowe aglomeracji trójmiejskiej czekają poważne transformacje funkcjonalne, prawdopodobnie o charakterze zbliżonym do tych, jakie przeszła większość dużych portów Europy Zachodniej i Ameryki Północnej.

Przyszłość terenów związanych z gospodarką morską zależy w znacznej mierze od przyszłości transportu morskiego i związanego z nim przemysłu stoczniowego, a także od struktury kierunkowej i branżowej polskiego handlu zagranicznego, rozwoju konkurencyjnych środków transportu i konkurencyjnych portów (zwłaszcza Hamburga. Bremenhaven, Szczecina - Świnoujścia i Kaliningradu) oraz od intencji, możliwości i sprawności organizacyjnej właścicieli tych terenów.

Poważnym zagrożeniem przyszłości rozwoju portów, a przez to i aglomeracji, może być postępująca konkurencja między portami Gdańska i Gdyni, walczących o ten sam segment rynku (w tym kontenery, zboża i inne), na podobnych przedpolach i zapleczach. Zarządy portów, pomimo wspólnego właściciela, którym pozostaje de facto Skarb Państwa, nie prowadzą wspólnej polityki inwestycyjnej, planowania strategicznego ani działań marketingowych, które bez wątpienia mogłyby pomóc działalności obu portów. 